\title{
INFLUENCE OF DIFFERENT MANAGERIAL SYSTEMS ON PERFORMANCE AND PHYSIOLOGICAL RESPONSES OF DEVELOPING BUFFALO CALVES DURING FATTENING PERIOD
}

\author{
M. Abd-Allah ${ }^{1 *}$, M.Y. Elaref $^{2}$ and A.I. Zanouny ${ }^{3}$ \\ 1- Animal Production Department, Faculty of Agriculture, Al-Azhar University, Assiut Branch, Assiut, Egypt, \\ 2- Animal Production Department, Faculty of Agriculture, Sohag University, Sohag, Egypt, 3- Animal \\ Production Department, Faculty of Agriculture, Minia University, Minia, Egypt, \\ *Corresponding author: E-mail: Mohtaram_a_m_e@yahoo.com. Tel: +20201006957157
}

\section{SUMMARY}

Sixteen yearling male buffalo calves weighing $160 \mathrm{~kg}$ were assigned to $2 x 2$ factorial designs. Each four calf group was subjected to either long (16L:8D) or short (8L:16D) photoperiods and housed in individual or group system. The four groups were fed CFM and wheat straw. Feed intake and residual were recorded daily. Samples of feces and food ration were collected for analysis. Digestion coefficients, nutritive values and feed efficiency were calculated. Animals were weighed biweekly. Blood samples were collected monthly to determine total protein, albumin, globulin, ALT/GPT, AST/GOT and total cholesterol. Housing systems did not have any significant effects on calf body weight and growth rate while; photoperiod had significant effect $(P \leq 0.01)$ on them. Housing systems did not have any significant effects on the digestion coefficients and nutritive values, while, photoperiod systems had highly significant $(P \leq 0.01)$ effect on digestibility coefficients and nutritive values of buffalo calves. Calves exposed to long photoperiod (16L:8D) and housed in group pens were more efficient in converting feed to gain than calves exposed to short photoperiod (8L:16D) and housed in individual pens. Total protein $(P \leq 0.05)$, albumin $(P \leq 0.01)$ and ALT/GPT $(P \leq 0.05)$ was significantly affected by the housing system. All blood parameters were not significantly affected except cholesterol level was significantly $(P \leq 0.01)$ affected by photoperiod. The interaction between housing systems and photoperiods did not have any significant differences on growth performance, feed conversion efficiency or metabolic response. It could be concluded that rearing buffalo calves individually with increasing illumination period to 16 hours/ day may improve feed efficiency and growth performance without compromising the physiological status of the calves during the fattening period.

Keywords: Buffalo calves, housing system, photoperiod, growth performance, feed efficiency

\section{INTRODUCTION}

Productivity of farm animals depends on the various processes of care and the extent of control, especially environmental ones. A photoperiod and housing system environmental factors can be controlled easily, which determines the productivity of animals, and in spite of that, it has not been studied sufficiently under Egyptian conditions. Cozzi et al. (2000) and Verga et al. (2000) studied the effect of group housing system in comparison with the traditional individual crate on growth performance, carcass traits and behavior of veal calves. Animals reared in group showed positive behavioral and growth responses due to the reduction of the isolation stress and the increasing in space allowance. Calves reared in group pens had higher feed efficiency and average daily gain than those reared in individual pens (Andrighetto et al., 1999), while Maatje et al. (1991) found that feed intake and growth rate of the group housed calves was lower than calves housed in individual crates.

Using group house might be beneficial for improving the welfare and socialization of the calf (Gulliksen et al., 2009). Group housing, containing two to six calves, provides more calf interactions and enriches their environment by adding stimulus (Stull and Reynolds, 2008). Several studies have shown higher intakes of solid feed in group housed calves, including calves reared on low milk allowance for one week (Babu et al., 2004; Phillips, 2004 and Hepola et al., 2006) or four weeks of age (Tapki, 2007), as well as in ad libitum fed calves (De Paula Vieira et al., 2010).

Productivity of livestock is influenced by photoperiod, light intensity, and light quality from birth and during the different stages of life. Research works have been carried out to study the possible effects of photoperiods in animals for various purpose such as, improvement of milk yield and their composition (Miller et al., 2000; Dahl and Petiticlerc, 2003 and Auchtung et al., 2005), reproduction and growth performance (Hansen et al., 1983; Small et al., 2003; Capuco et al., 2003; Moallem et al., 2004 and Rius et al., 2005), dry matter intake (Dahl et al., 2000; Dahl and Petitclerc, 2003 and Karvetski et al., 2006); physiological responses and immune function (Kendall et al., 2003; Auchtung et al., 2005 and Wall et al., 2005). The objective of this study was to investigate the effect of photoperiods and housing system on calves' performance during fattening period such as growth performance, feed efficiency and some blood constituents. 


\section{MATERIALS AND METHODS}

The present study was conducted at Animal Production farm belonging to Faculty of Agriculture, Al-Azhar University, Assiut Branch, from April to August, 2012, to study the impact of photoperiod and housing system as management systems on the productivity of buffalo calves during the fattening period.

Sixteen male Egyptian buffalo calves aging one year with an average weight $160 \mathrm{~kg}$ were included in fattening experiment lasted 120 day and divided randomly into four equal groups, four calves/each. The experiment was designed as $2 \times 2$ factorial design, to study the effect of two photoperiods of 16 hour of light: 8 hour of dark (16L:8D) or eight hour of light : 16 hour of dark (8L:16D) and the effect of two housing systems group pens or individual pens. Calves housed in group pens $\left(5 \mathrm{~m}^{2} / \mathrm{head}\right)$ or individual pens $2 \times 2.7 \mathrm{~m}\left(5.4 \mathrm{~m}^{2} /\right.$ head $)$. Calves which are exposed to photoperiod either a long day 16L:8D (Light switched on from 8 to $24 \mathrm{~h} /$ day) or a short day 8L:16D (Light switched on from 8 to 16 h/day). Fluorescent lights were used to provide lighting at an intensity of approximately $600 \mathrm{~lx}$ at the eye level of calves to simulate the lighting outside (light density inside pen was equal to the normal daylight (outside pen)). Animals were weighed at the beginning of the experiment and thereafter at biweekly intervals. The buffalo calves were fed concentrate feed mixture (CFM), and the CFM was offered at the rate of $2.5 \%$ of body weight, while wheat straw and fresh water were freely available all times. The nutrient requirements were changed according to change in body weight according to NRC (1985) recommendations. At the end of the fattening trial three calves from each group were used in a metabolic trial to determine nutrients digestibility and nutritive values, and feed efficiency ( $\mathrm{kg} / \mathrm{kg}$ gain). Daily feed consumed and residuals were accurately weighed and recorded, daily weight gain and feed conversion were calculated. Composite samples of feces and ration were prepared by drying, grinding and stored in tight jars for further chemical analysis (DM, CP, CF, EE and ash contents). The composition and approximate chemical analysis of CFM are shown in Table (1).

Blood samples were collected from the jugular vein of the treated groups into heparinized tubes at the end of the experiment. The samples were transported in ice box to the laboratory within 20-30 minutes, centrifuged at $4000 \mathrm{rpm}$ for 20 minutes. Plasma was stored at $-20^{\circ} \mathrm{C}$ till the biochemical analysis. Total plasma protein, albumin, glucose, AST, ALT and cholesterol concentrations were determined by using kit supplied by Diamond Diagnostic Company and according to the methods described by Varley (1976). However, globulin concentration was calculated by difference between total proteins and albumin.

\section{Statistical analysis}

Analyses of variance were performed on all the variables measured by using the general linear models (GLMs) procedure of SAS (1998) according to the following model:

$\mathrm{Y}_{\mathrm{ijk}}=\mu+\mathrm{P}_{\mathrm{i}}+\mathrm{Hj}+\mathrm{PH}_{\mathrm{ij}}+\mathrm{e}_{\mathrm{ijk}}$

Where: $\mu=$ general mean, $\mathrm{P}_{\mathrm{i}}=$ Effect of photoperiod (1=long and $2=$ short); $\mathrm{Hj}=$ Effect of housing system (1=individual and $2=$ groups), $\mathrm{PH}_{\mathrm{ijk}}=$ effect of interaction between photoperiod and housing system and $\mathrm{e}_{\mathrm{ijk}}=$ error related to individual observation. Duncan's multiple range tests (1955) was utilized for determining differences among subgroups means.

Table 1. Composition and approximate chemical analysis of CFM offered to buffalo calves during fattening period (on DM basis \%)

\begin{tabular}{|c|c|c|c|}
\hline \multirow{2}{*}{$\begin{array}{l}\text { Ingredients } \\
\text { Yellow corn }\end{array}$} & \multirow{2}{*}{$\begin{array}{l}\% \\
35\end{array}$} & \multicolumn{2}{|c|}{ Chemical composition } \\
\hline & & $\mathrm{DM}$ & 89.67 \\
\hline Wheat bran & 25 & $\mathrm{OM}$ & 87.94 \\
\hline Undecorticated cotton seed meal & 20 & $\mathrm{CP}$ & 12.06 \\
\hline Rice chaff & 14 & $\mathrm{EE}$ & 3.76 \\
\hline Molasses & 3 & $\mathrm{CF}$ & 13.47 \\
\hline Limestone & 1 & NFE & 58.66 \\
\hline Mineral mix and vit. (Premix) & 1 & Ash & 8.87 \\
\hline Common salts & 1 & *GE, Mcal/kg DM & 4.03 \\
\hline
\end{tabular}

* GE $(\mathrm{Mcal} / \mathrm{Kg} \mathrm{DM})=$ CP x 5.65 + CF x 4.15 + EE x 9.40 + NFE x 4.15 (Blaxter, 1968) 


\section{RESULTS}

\section{Growth performance:}

The effects of the housing system and photoperiod on calf growth performance are reported in Table (2). The results indicate that there is a slight increase in the final body weight and growth rate of the calves reared in individual crates than calves reared in groups, while no significant differences were observed in growth performance during the experiment period. There were no significant differences in initial and final body weight between calves exposed to long (16L:8D) or short (8L:16D) photoperiods, although buffalo calves subjected to long photoperiod had the highest rate of growth by $2.87 \%$ in final body weight than those in short photoperiod. On the other hand, photoperiod had a significant effect $(\mathrm{P}<0.01)$ on total gain and average daily gain through the experimental period. The total gain and average daily weight gain was (113 vs. 106) and $(0.942 v s .0 .883 \mathrm{~kg})$ for calves in long (16L:8D) or short (8L:16D) photoperiod, respectively. Interaction between photoperiod and housing systems did not have any significant effect on the final body weight or growth rate of buffalo calves.

Table 2. Effect of photoperiod and housing systems on growth performance of buffalo calves during fattening period (120 days from about $160 \mathrm{~kg}$ body weight)

\begin{tabular}{|c|c|c|c|c|}
\hline \multirow{2}{*}{ Items } & \multicolumn{4}{|c|}{$\mathbf{L S M} \pm \mathbf{S E}$} \\
\hline & Initial weight $(\mathbf{k g})$ & Final weight $(\mathrm{kg})$ & Total gain (kg) & Daily gain (kg) \\
\hline Housing system & ns & ns & ns & ns \\
\hline Group & 160.00 & 268.25 & 108.25 & 0.902 \\
\hline Individual & 161.13 & 271.88 & 110.75 & 0.923 \\
\hline S.E & 12.135 & 12.054 & 1.163 & 0.009 \\
\hline Photoperiod & ns & ns & $* *$ & $* *$ \\
\hline Long & 161.00 & 274.00 & 113.00 & 0.942 \\
\hline Short & 160.13 & 266.13 & 106.00 & 0.883 \\
\hline S.E & 12.135 & 12.054 & 1.163 & 0.009 \\
\hline Housing x Photoperiod & ns & ns & ns & ns \\
\hline Group x Short & 163.50 & 269.00 & 105.50 & 0.879 \\
\hline Group x Long & 156.50 & 267.50 & 111.00 & 0.925 \\
\hline Individual x Short & 156.75 & 263.25 & 106.50 & 0.887 \\
\hline Individual x Long & 165.50 & 280.50 & 115.00 & 0.958 \\
\hline S.E & 17.162 & 17.046 & 1.645 & 0.013 \\
\hline
\end{tabular}

**= significant $(\mathrm{P}<0.01) ; \mathrm{ns}=$ not significant $(\mathrm{P}>0.05)$

\section{Digestibility coefficients, nutritive values and feed efficiency:}

Digestibility coefficients, nutritive values and feed efficiency of buffalo calves exposed to long or short photoperiod individually or group housed systems during fattening period are presented in Tables (3) and (4), respectively.

Housing systems did not have any significant effect on the digestion coefficients and nutritive values, while a slight increase was observed in the digestibility coefficients and nutritive values of the calves, which housed in individual cages compared to calves housed in groups. From Table (3) it is clear that the digestion coefficients and nutritive values of calves exposed to long photoperiods (16L:8D) were significantly $(\mathrm{P} \leq 0.01)$ higher than calves offered for short photoperiods (8L:16D). Digestibility coefficients of $\mathrm{CP}, \mathrm{EE}, \mathrm{CF}$ and NFE were higher by $13.5,7.13,48.3$ and $19.95 \%$, respectively. Also, nutritive values were higher by 25.61, 13.44 and 20.7 $\%$ for TDN, DCP and ME, respectively. Interaction between housing systems and photoperiod did not have any significant effect on the digestion coefficients. The effect of photoperiod and housing system on feed conversion efficiency $\mathrm{kg} / \mathrm{kg}$ gain of buffalo calves are shown in Table (4). Calves exposed to long photoperiod (16L:8D) and raised in group pens are more efficient in converting feed to gain than those of calves exposed to short photoperiod (8L:16D) and raised in individual pens.

\section{Blood constituents:}

Least squire means \pm standard error of some blood constituents of buffalo calves treated by two housing and two photoperiod systems are shown in Table (5). Total protein $(\mathrm{P} \leq 0.05)$, albumin $(\mathrm{P} \leq 0.01)$ and alanine aminotransferase (ALT/GPT, $\mathrm{P} \leq 0.05$ ) was significantly affected by the housing system; the level of these components was higher in calves housed individually than calves housed in groups. In spite of plasma globulin, aspartate aminotransferase (AST) and cholesterol concentration remained lower in calves raised in groups than calves raised as individual but this reduction was not statistically significant. On the other hand, photoperiod did not have any significant effect on the majority of blood components with the exception of cholesterol level, which was significantly affected $(\mathrm{P} \leq 0.01)$. There was non-significant increase in the level of plasma proteins and (ALT/GPT) in calves offered a long 
photoperiod (16L:8D), while it was observed that, there was insignificant rise in the level of (AST/GOT) and highly significant in the level of cholesterol in the calves offered short photoperiods (8L:16D). Results in Table (5) show that there were no significant differences of the interaction between housing and photoperiod systems, but it was illustrated that, all the blood parameters were slightly higher in calves which were raised in individual pens and exposed to long photoperiods, except cholesterol level was higher in calves raised in groups and offered short photoperiods.

Table 3. Digestibility coefficients and nutritive values of buffalo calves exposed to long or short photoperiod and kept under two housing systems (individual or groups) during fattening period

\begin{tabular}{|c|c|c|c|c|c|c|c|c|c|}
\hline \multirow{2}{*}{ Items } & \multicolumn{6}{|c|}{ Digestibility coefficients, $\%$} & \multicolumn{2}{|c|}{ Nutritive values, \% } & \multirow{2}{*}{$\begin{array}{c}\text { ME, } \\
\mathrm{Mcal} / \mathrm{kg} \\
\mathrm{DM}\end{array}$} \\
\hline & DM & OM & $\mathbf{C P}$ & $\mathbf{E E}$ & CF & NFE & TDN & DCP & \\
\hline Housing system & $\mathrm{ns}$ & $\mathrm{ns}$ & ns & $\mathrm{ns}$ & $\mathrm{ns}$ & ns & ns & ns & ns \\
\hline Group & 63.38 & 63.58 & 74.46 & 85.10 & 39.50 & 65.49 & 59.91 & 8.98 & 2.16 \\
\hline Individual & 64.29 & 64.48 & 75.09 & 85.47 & 41.01 & 66.35 & 60.72 & 9.06 & 2.19 \\
\hline S.E & 2.206 & 2.194 & 1.538 & 0.897 & 3.644 & 2.078 & 1.971 & 0.185 & 0.070 \\
\hline Photoperiod & $* *$ & $* *$ & $* *$ & $* *$ & $* *$ & $* *$ & $* *$ & $* *$ & $* *$ \\
\hline Long & 71.59 & 71.74 & 80.19 & 88.44 & 53.06 & 73.22 & 67.25 & 9.67 & 2.42 \\
\hline Short & 56.08 & 56.31 & 69.37 & 82.13 & 27.44 & 58.61 & 53.39 & 8.37 & 1.92 \\
\hline S.E & 2.206 & 2.194 & 1.538 & 0.897 & 3.644 & 2.078 & 1.971 & 0.185 & 0.070 \\
\hline Housing x Photoperiod & $\mathrm{ns}$ & $\mathrm{ns}$ & $\mathrm{ns}$ & $\mathrm{ns}$ & $\mathrm{ns}$ & $\mathrm{ns}$ & ns & $\mathrm{ns}$ & ns \\
\hline Group x Short & 56.51 & 56.74 & 69.67 & 82.30 & 28.15 & 59.02 & 53.77 & 8.40 & 1.94 \\
\hline Group x Long & 70.24 & 70.41 & 79.25 & 87.89 & 50.85 & 71.96 & 66.05 & 9.56 & 2.38 \\
\hline Individual x Short & 55.64 & 55.89 & 69.07 & 81.95 & 26.73 & 58.20 & 53.00 & 8.33 & 1.91 \\
\hline Individual x Long & 72.93 & 73.07 & 81.12 & 88.98 & 55.28 & 74.49 & 68.45 & 9.78 & 2.46 \\
\hline S.E & 3.120 & 3.103 & 2.175 & 1.269 & 5.153 & 2.939 & 2.788 & 0.262 & 0.100 \\
\hline
\end{tabular}

$\mathrm{DM}=$ dray matter, $\mathrm{OM}=$ organic matter, $\mathrm{CP}=$ crude protein, $\mathrm{EE}=$ ether extract (fat), $\mathrm{CF}=$ crude fiber, $\mathrm{NFE}=$ nitrogen free extract, $\mathrm{TDN}=$ total digestible nutrients, $\mathrm{DCP}=$ digestible crude protein and $\mathrm{ME}=$ metabolizable energy.

Table 4. Feed conversion efficiency of buffalo calves exposed to long or short photoperiod and kept under two housing systems (individual or group) during fattening period (120 days from $160 \mathrm{~kg} \mathrm{BW}$ )

\begin{tabular}{lcccc}
\hline \multirow{2}{*}{ Items } & \multicolumn{2}{c}{ Housing } & \multicolumn{2}{c}{ Photoperiod } \\
\cline { 2 - 5 } & Group & Individual & Long & Short \\
\hline DMI, $\mathrm{kg} / \mathrm{h} / \mathrm{d}$ & 5.33 & 6.10 & 4.95 & 6.32 \\
TDN intake, $\mathrm{kg} / \mathrm{h} / \mathrm{d}$ & 2.66 & 3.09 & 2.77 & 2.81 \\
ME intake, Mcal/h/d & 11.51 & 13.34 & 11.98 & 12.14 \\
DCP intake, $\mathrm{kg} / \mathrm{h} / \mathrm{d}$ & & & & \\
\hline Feed conversion efficiency, kg/kg gain & 0.40 & 0.46 & 0.40 & 0.44 \\
DM & & & & \\
TDN & 4.93 & 5.51 & 4.38 & 5.96 \\
DCP & 2.46 & 2.79 & 2.45 & 2.65 \\
\hline DMI dy & 0.37 & 0.42 & 0.35 & 0.42 \\
\hline
\end{tabular}

$\mathrm{DMI}=$ dry matter intake, $\mathrm{TDN}=$ total digestible nutrients, $\mathrm{ME}=$ metabolizable energy, $\mathrm{DCP}=$ digestible crude protein 
Table 5. Effect of photoperiod and housing systems on some blood parameters of buffalo calves during fattening period (120 days from $160 \mathrm{~kg}$ body weight)

Blood constituents of calves fattened for 120 days from $160 \mathrm{~kg} \mathrm{BW}$

\begin{tabular}{lccccccc}
\cline { 2 - 7 } \multicolumn{1}{c}{ Items } & $\begin{array}{c}\text { Total } \\
\text { protein } \\
(\mathrm{g} / \mathrm{dl})\end{array}$ & $\begin{array}{c}\text { Albumin } \\
(\mathrm{g} / \mathrm{dl})\end{array}$ & $\begin{array}{c}\text { Globulin } \\
(\mathrm{g} / \mathrm{dl})\end{array}$ & $\begin{array}{c}\text { A/G } \\
\text { ratio }\end{array}$ & $\begin{array}{c}\text { ALT/GPT } \\
(\mathrm{U} / \mathrm{l})\end{array}$ & $\begin{array}{c}\text { AST/GOT } \\
(\mathrm{U} / \mathrm{l})\end{array}$ & $\begin{array}{c}\text { Cholesterol } \\
(\mathrm{mg} / \mathrm{dl})\end{array}$ \\
\hline Housing system & $*$ & $* *$ & $\mathrm{~ns}$ & $\mathrm{~ns}$ & $*$ & $\mathrm{~ns}$ & $\mathrm{~ns}$ \\
Group & 7.905 & 4.173 & 3.732 & 1.139 & 41.90 & 23.80 & 211.45 \\
Individual & 8.693 & 4.568 & 4.124 & 1.1188 & 46.50 & 27.00 & 223.53 \\
S.E & 0.234 & 0.1046 & 0.169 & 0.0502 & 1.466 & 1.385 & 7.925 \\
\hline Photoperiod & $\mathrm{ns}$ & $\mathrm{ns}$ & $\mathrm{ns}$ & $\mathrm{ns}$ & $\mathrm{ns}$ & $\mathrm{ns}$ & $* *$ \\
Long & 8.525 & 4.439 & 4.086 & 1.0999 & 45.600 & 25.00 & 202.59 \\
Short & 8.072 & 4.303 & 3.770 & 1.157 & 42.800 & 25.800 & 232.39 \\
S.E & 0.234 & 0.1046 & 0.169 & 0.0502 & 1.466 & 1.385 & 7.925 \\
\hline Housing x Photoperiod & $\mathrm{ns}$ & $\mathrm{ns}$ & $\mathrm{ns}$ & $\mathrm{ns}$ & $\mathrm{ns}$ & $\mathrm{ns}$ & $\mathrm{ns}$ \\
Group x Short & 7.566 & 4.049 & 3.518 & 1.174 & 39.60 & 23.80 & 234.44 \\
Group x Long & 8.243 & 4.298 & 3.945 & 1.104 & 44.20 & 23.80 & 188.46 \\
Individual x Short & 8.578 & 4.556 & 4.0218 & 1.140 & 46.00 & 27.80 & 230.33 \\
Individual x Long & 8.807 & 4.580 & 4.227 & 1.096 & 47.00 & 26.20 & 216.74 \\
S.E & 0.3311 & 0.1479 & 0.2392 & 0.0710 & 2.0736 & 1.959 & 11.207 \\
\hline
\end{tabular}

$* *=$ significant $(\mathrm{P}<0.01) ; *=$ significant $(\mathrm{P}<0.05) ; \mathrm{ns}=$ not significant $(\mathrm{P}>0.05) . \quad \mathrm{A} / \mathrm{G}$ ratio $=$ Albumin/Globulin ratio, $\mathrm{ALT} / \mathrm{GPT}=$ alanine aminotransferase, $\mathrm{AST} / \mathrm{GOT}=$ aspartate aminotransferase.

\section{DISCUSSION}

Using loose house for calves improves their welfare and makes it more comfort by increasing movement and social relationship, stimulates growth performance when compared to traditional housing with tethers in individual stalls (Xiccato et al., 2002). Data recorded on the effects of group housing is rather contrasting. Calves daily gain throughout the experimental period was not significantly affected by the housing system and resulted as $913 \mathrm{~g} /$ day on average. However, a slight increasing in daily gain was measured for individual calves than calves housed in group during the period of the experimental (923 vs. $902 \mathrm{~g} /$ day) as a result of better feed efficiency (Table 2). This result is in agreement with Maatje et al., (1991) who found that the growth rate of group housed calves was lower than those housed in individual crates. In sheep, Abd-Allah (2002) reported that effect of housing system on body weight of lambs was not significant; lambs housed in group pen have higher final body weight than those housed in individual pen by about $2.5 \%$. In contrast, Andrighetto et al. (1999) reported that calves in group pens had higher average daily gain than calves in individual crates during the last 72 days of the experiment. Calves reared in groups showed higher final live weight than calves reared individually $(255$ vs. $249 \mathrm{~kg}, \mathrm{P} \leq 0.05)$ due to the higher daily weight gain $(\mathrm{P}<0.001)$ during the second period (Xiccato et al., 2002). Results of Wójcik, et al. (2013) revealed that during the first month, the calves from both groups achieved the same daily gains. However, older calves kept in-door were characterized by better daily gains, feed intake and as a result, body weight.

Forbes et al. $(1975,1979)$ reported an increase in live weight gain of castrated male or intact ewe lambs exposed to 16L:8D photoperiods as compared with animals exposed to 8L: 16D. This is in agreement with previous data in cattle calves (Guertin et al., 1995) who found that veal calves exposed to long day photoperiod 16L: 8D gained more than those exposed to 10L: $8 \mathrm{D}$. In cattle, live weight gain increased by $11 \%$ to $17 \%$ in heifers exposed to $16 \mathrm{~L}: 8 \mathrm{D}$ over that heifers exposed to natural duration photoperiods of 9 to $12 \mathrm{~h}$ daily (Peters et al., 1978) or 8L:16D (Peters et al., 1980 and Petitclerc et al., 1983).

In pre-pubertal heifers, photoperiod did not affect average daily body weight gain; however, postpubertal heifers exposed to short-day photoperiods had greater body weight daily gain than animals exposed to long-day photoperiods (Zinn et al., 1986a). Furthermore, Abd-Allah (2002) found that, there was no significant difference in initial or final body weight of lambs exposed to long or short photoperiod. In addition, lambs exposed to long photoperiod gained more significant in weight by $23.8 \%$ than lambs exposed to short photoperiod. Peters and Tucker (1978) attributed the reason for the increase in the growth rate when animals are exposed to long photoperiod to increase stimulation and revitalization of the endocrine secretion of growth hormone. Increasing daily light exposure from 8 to 16 $\mathrm{h}$ increases average daily body weight gains of sheep and Holstein cattle but reduces gains of white-tailed doe fawns (Tucker et al., 1984). Photoperiod manipulation, therefore, offers a management tool that could enhance growth and accelerate the onset of puberty (Petitclerc et al., 1983 and Schillo et al., 1992).

In similarity with the present study, Babu et al.(2003) found that, digestibility of dry matter (DM), 
organic matter, total carbohydrate, ether extract and crude protein (CP) were non-significant different between the rearing systems (individuals $v s$. groups) and the feeding schedules. Recent findings suggest that, buffalo calves exposed to long photoperiod and raised in group pen are more efficient in converting feed to gain than calves exposed to short photoperiod and raised in individual crates. Babu et al. (2003) attributed this to cohabitation in group housed animals induced learning to eat solid feed earlier, and also at higher amounts compared to individually fed animals. The number of calves reared per pen did not affect daily gain, the intake of milk replacer and straw and feed efficiency (Gottardo et al., 2005). When calves were reared individually, the possibility for movement in larger cages without tethering improves weight gain and feed efficiency in comparison with animals kept in small cages with tethers (Fisher et al., 1985). De Paula Vieira et al. (2010) found that weaning pair-housed calves resumed concentrate feeding more rapidly and consumed more concentrate than individually housed calves. Duve et al. (2012) found that pair-housed calves more quickly accessed concentrates and spent more time eating concentrates than individually housed calves when the space at the feed manger was limited.

Lactating cows exposed to a long day photoperiod have higher DMI compared with those without extended light exposure (Dahl et al., 2000 and Dahl and Petitclerc, 2003). One possible explanation for altered intake of cows on different photoperiods is the feeding time. Does light exposure influence the amount of time that cows spend on feeding?. Studies in heifers and dry cows suggest that shifts in total feeding time do not account for differences in intake (Zinn et al., 1986b and Karvetski et al., 2006). Some explanation suggests that the amount of feed intake varies according to the change in the time when cows are exposed to a photoperiod (Karvetski et al., 2006). Sheep and heifers exposed to 16L:8D grew faster and consumed more dry matter than similar animals reared under 8L:16D photoperiods (Peters et al., 1980 and Petitclerc et al., 1983). Nonetheless, 16L: 8D photoperiods induced greater efficiency in terms of feed to gain ratio. Schanbacher and Crouse (1981) found that, sheep given photoperiods of 7L:9D : 1L:7D consumed less feed per unit of body weight gain than control animals given $8 \mathrm{~h}$ of light as a continuous block each day. This improvement in feed conversion efficiency ( $\mathrm{kg} / \mathrm{kg}$ gain) probably is due to the high growth rate or high concentrate mixture intakes by calves exposed to long photoperiod 16L: 8D.

Results from Table (5) indicate that, total protein, albumin and ALT/GPT levels are significantly affected by housing system, while there was no significant effect on the levels of globulin, A/G ratio, AST/GOT and cholesterol. All blood components were higher in calves raised in individual pens than those that were housed in group pens. It could be due to the suffering of calves raised in group from a lack of ventilation or space available compared to calves raised individually, which got a full diet compared to that raised in groups. Coban and Sabuncuoglu (2005) studied the effect of barn type on blood characteristics of dairy calves. All blood parameters that they measured were significantly affected by type of barn (open shed and stall barn) except erythrocyte counts. Overall mean of plasma glucose and urea concentration in lambs raised in group pen was higher $(\mathrm{P}<0.05)$ than those lambs raised in individual pens (Abd-Allah, 2002). Friend et al. (1985) housed calves in stalls, pens, hutches and groups. Calves housed in pens or stalls had elevated neutrophils, total serum protein, Ca, blood urea nitrogen, creatine kinase, triiodothyronine, thyroxine, and adrenal response to ACTH compared to those housed in hutches or pens.

The present data indicated that, photoperiods did not have a significant effect on total protein, albumin, globulin, ALT/GOT and AST/GPT. However, significant differences $(\mathrm{P} \leq 0.01)$ were found among cholesterol levels. These results are consistent with that obtained by Kassim Nany et al. (2008). They found that, total protein and albumin concentration of buffalo heifers exposed to 16L: 8D or 8L: 16D during autumn and winter season were not significant but differ among treatments groups. Globulin, T3, T4, glucose and triglycerides were significantly increased $(\mathrm{P}<0.05)$ by increasing photoperiod. The high level of cholesterol in the calves in the short day photoperiod (8L: 16D) may be due to increased deposition of fat in the blood vessels as a result of reduced muscle activity. Piccione et al. (2012) studied the effect of annual changes of some metabolic parameters in dairy cows and found a significant effect of time of year $(\mathrm{P}<0.001)$ for all blood parameters, except for non-esterified fatty acids (NEFA). Similar results were obtained by Afify et al. (2004) and Hassan et al. (2004).

\section{CONCLUSION}

The results of the current study suggest that, body weight, total gain, average daily gain, digestion coefficients and nutritive values were improved during fattening period (from $160 \mathrm{~kg} \mathrm{BW}$ for 120 days) of veal buffalo calves when housed individually and exposed to long photoperiod 16L: 8D. Similarly, the metabolic responses of blood parameters were higher in calves housed individually and offered a long photoperiod. From these results it can be concluded that rearing buffalo calves individually with increasing illumination period to 16 hours/ day will offer a better chance for calves to get high amount of food and improve growth rate than other systems.

\section{REFERENCES}

Abd-Allah. A.M., 2002. Performance of Ossimi lambs under different managerial systems during 
fattening period. M.Sc. Thesis, Faculty of Agric, Assiut Univ, Egypt.

Afify A.A., Z. Hassan, S.I. Hoda, Kassim Nany and S. Awad Set El-Habaeib, 2004. Effect of photoperiod on productive and reproductive performance of primiparous buffaloes. Annals of Agric. Sci., Moshtohor, Zagazig Univ., Egypt, 42(4): 1537-1547.

Andrighetto I. F., Gottardo, D. Andreoli, and G. Cozzi, 1999. Effect of type of housing on veal calf growth performance, behaviour and meat quality. Livestock Production Science. 57 (2) 137-145

Auchtung T.L., A.G. Rius, P.E. Kendall, T.B. McFadden, and G.E. Dahl, 2005. Effects of photoperiod during the dry period on prolactin, prolactin receptor, and milk production of dairy cows. J. Dairy Sci, 88: 121-127.

Babu L. K., H. N. Pandey and A. Sahoo, 2003. Effect of individual versus group rearing and feeding of different levels of milk and skim milk on nutrient utilization in crossbred calves. Asian-Aust. J. Anim. Sci, 16 (10) : 1455-1459.

Babu L.K., H.N. Pandey and A. Sahoo, 2004. Effect of individual versus group rearing on ethological and physiological responses of crossbred calves. Appl. Anim. Behav. Sci, (87):177-191.

Blaxter K.L, 1968. The energy metabolism of ruminants. $2^{\text {nd }}$ Ed., Charles Thomas Publisher, Springfield, Illinois, USA.

Capuco A. V., R. Erdman, G. Dahl, M. Meyer and M.Van Amburgh, 2003. Heifer Nutrition Prepubertal Growth and Development. Proc. 50th Maryland Nutr. Conf. Feed Manufacturers and 1st Mid-Atlantic Nutr. Conf., Timonium, MD. University of Maryland, College Park.

Coban O. and N. Sabuncuoglu, 2005. Blood characteristics of dairy calves as affected by age, breed and types of barn. Journal of Animal and Veterinary Advances, 4 (4): 459- 461.

Cozzi G., F. Gottardo, D. Andreoli, I. Andrighetto, S. Mattiello, V. Ferrante and M. Verga, 2000. Administration of a solid feed to veal calves housed in individual cages or in group box. 1 . Performance production and meat quality. Zoot. Nutr. Anim, (26): 233-242.

Dahl G.E. and D. Petitclerc, 2003. Management of photoperiod in the dairy herd for improved production and health. J. Anim. Sci, 81(3):11-17.

Dahl G.E., B.A. Buchanan and H.A. Tucker, 2000. Photoperiodic effects on dairy cattle: A review. J. Dairy Sci, (83):885-893.

De Paula Vieira A., M.A.G. von Keyserlingk and D.M. Weary, 2010. Effects of pair versus single housing on performance and behaviour of dairy calves before and after weaning from milk. J. Dairy Sci, (93): 3079-3085.

Duncan D. B, 1955. Multiple range and multiple Ftest. Biometrics, 11: 1.

Duve L. R., D. M. Weary, U. Halekoh and M. B. Jensen, 2012. The effects of social contact and milk allowance on the response to handling, play behavior and social behavior in young dairy calves. J. Dairy. Sci, (95):6571-6581.

Fisher L.J., G.B. Peterson, S.E. Jones and J.A. Shelford, 1985. Two housing systems for calves. J. Dairy. Sci, (68): 368-373.

Forbes J. M., A. A. E1 Shahat, R. Jones., J.G.S. Duncan and T. G. Boaz, 1979. The effect of daylength on thegrowth of lambs. I. Comparisons of sex, level of feeding and shearing and breed of sire. Anim. Prod, 29: 33.

Forbes J. M., P. M. Driver, A. A. El Shahat, T. G. Boaz and C. G. Scanes, 1975. The effect of daylength and level of feeding on serum prolactin in growing Iambs. J. Endocrinol, (64): 549.

Friend T. H., G. R. Dellmeier and E.E. Gbur, 1985. Comparisons of four methods of calf confinement. I. Physiology. J. Anim. Sci, (60):1095-1101.

Gottardo F., M. Dorigo and G. Cozzi, 2005. Effect of number of animals per pen on growth performance and meat quality of veal calves. Ital. J. Anim. Sci, 4 (2): 260-262.

Gulliksen S. M., E. Jor, K.I. Lie, T. Loken, J. Akerstedt and O. Osteras, 2009. Respiratory infections in Norwegian dairy calves. American Diary Science Association, (92): 5139- 5146.

Guertin G., B. Lachance, G. Plletier, G. J. StLaurent, G.L. Roy and D. Petitclerc, 1995. Effects of photoperiod and feeding whole maize, whole barley or rolled barley on growth performance and diet digestibility in veal calves. Livestock Production Science, 44 (1): 27-36.

Hansen P. J., L. A. Kamwanja and E. R. Hauser, 1983. Photoperiod influences age at puberty of heifers. J. Anim. Sci, (57) : 985-992.

Hassan Hoda Z., A.A. Afify, S.I. Kassim Nany and M. Zeidan Soheir, 2004. Effect of photoperiod length on growth and some physiological aspects of buffalo heifers. Annals of Agric. Sci., Moshtohor, Zagazig Univ., Egypt, (42): 15251535.

Hepola H. L., P. Hänninen, V.M. Pursiainen, L. Tuure., M. Syrjälä-Qvist., M. Pyykkönen and H. Saloniemi, 2006. Feed intake and oral behavior of dairy calves housed individually or in groups in warm or could buildings. Livest. Sci, (105):94104.

Karvetski K.E., J.M. Velasco, E.D.Reid, J.L. SalakJohnson and G.E. Dahl, 2006. Behavioral time budget of dry cows: Photoperiod alters distribution of maintenance behaviors. J. Anim. Sci, 84 (1): 410.

Kassim Nany S.I., A.A. Afify and Hoda Z. Hassan, 2008. Effect of Photoperiod Length on Some Reproductive Traits and Hormonal Profiles in Buffalo Heifers. American-Eurasian J. Agric. \& Environ. Sci, 3 (4): 646-655.

Kendall P.E., T.L. Auchtung, K.S. Swanson, R.P. Radcliff., M.C. Lucy, J.K. Drackley and G.E. Dahl, 2003. Effect of photoperiod on hepatic growth hormone receptor $1 \mathrm{~A}$ expression in steer calves. J. Anim. Sci, (81):1440-1446. 
Maatje K. J. Verhoeff, J. H. M. Metz and C. M. Groenestein, 1991. Automated feeding of milk replacer and helth control of group housed veal calves. New trend in veal calf production. Proceeding of the international symposium on veal calf production, Wageningen, Netherlands, 14- 16 March. 71-75.

Miller A.R.E., L.W. Douglass, R.A. Erdman and G. E. Dahl, 2000. Effects of photoperiodic manipulation during the dry period of dairy cows. Dairy Sci. 83:962-967. Dahl, G.E., B.A. Buchanan, and H.A. Tucker. 2000. Photoperiodic effects on dairy cattle: A review. J. Dairy. Sci, (83):885-893.

Moallem U., G. E. Dahl, E.K. Duffey, A.V. Capuco and R. A. Erdman, 2004. Bovine somatotropin and rumen undegradable protein effects on skeletal growth in prepubertal dairy heifers. J. Dairy Sci, (87):3881-3888.

N.R.C, 1985. Nutrient requirements of sheep. $\left(6^{\text {th }}\right.$ Ed.) National Academy of sciences, National Research Council, Washington, D. C.

Peters R. R. and H. A. Tucker, 1978. Prolactin and growth hormone responses to photoperiod. Endocrinology, (103):229.

Peters R. R., L. T. Chapin, K. B. Leining and H. A. Tucker, 1978. Supplemental lighting stimulates growth and lactation in cattle. Science, Feb 24; 199 (4331): $911-2$.

Peters R. R., L. T. Chapin., R. S. Emery and H. A. Tucker, 1980. Growth and hormonal response of heifers to various photoperiods. J. Anim. Sci, (51): 1148 .

Petitclerc D., L. T. Chapin, P. A. Harkins and H. A. Tucker, 1983. Evidence for photosensitive regulation of prolactin secretion in prepubertal bulls. Proc. Soc. Exp. Biol. Med, (172):478.

Phillips C.J.C, 2004. The effects of forage provision and group size on the behavior of calves. J. Dairy Sci, (87): 1380-1388.

Piccione G., V. Messina., S. Scianó., A. Assenza., T. Orefice., I. Vazzana and A. Zumbo, 2012. Annual changes of some metabolical parameters in dairy cows in the Mediterranean area. Veterinarski Arhiv, 82 (3): 229-238.

Rius A.G., E.E. Connor, A.V. Capuco, P. E. Kendall, T. L. Auchtung-Montgomery and G. E. Dahl, 2005. Long-Day Photoperiod that Enhances Puberty Does Not Limit Body Growth in Holstein Heifers. J. Dairy Sci, (88):4356-4365.

SAS, 1998. SAS User's guide: Statistics. SAS Inst. Inc., Cary,NC, Releigh.

Schanbacher B.D. and J. D. Crouse, 1981. Photoperiodic regulation of growth: A photosensitive phase during light-dark cycle. Amer. J. Physiol. 241(1):E1-5.

Schillo K. K., J. B. Hall and S. M. Hileman, 1992. Effects of nutrition and season on the onset of puberty in the beef heifer. J. Anim. Sci, (70):3994-4005.

Small J. A., N.D. Glover, A.D. Kennedy, W.P. McCaughey and D.R. Ward, 2003. Photoperiod effects on the development of beef heifers. Can. J. Anim. Sci, (83): 721-730.

Stull C. and J. Reynolds, 2008. Calf Welfare. Vet Clin Food Anim, (24): 191- 203.

Tapki I., 2007. Effects of individual or combined housing systems on behavioural and growth responses of dairy calves. Acta Agric. Scand, (57): 55- 60.

Tucker H. A., D. Petitclerc and S. A. Zinn, 1984. The influence of photoperiod on body weight gain, body composition, nutrient intake and hormone secretion. J. Anim. Sci, (59):1610.

Varley H., 1976. Practical Clinical Biochemistry. $4^{\text {th }}$ Ed., New Delhi, India.

Verga M., E. Canali, V. Ferrante, S. Mattiello, F. Monti, F. Gottardo, G. Cozzi and I. Andrighetto, 2000. Administration of a solid feed to veal calves housed in individual cages or in group box. 2Parameters behavioral, physiological and pathological. Zoot. Nutr. Anim, (26): 243-252.

Wall E.H., T.L. Auchtung, G.E. Dahl, S.E. Ellis and T.B. McFadden, 2005. Exposure to short day photoperiod enhances mammary growth during the dry period of dairy cows. J. Dairy Sci, (88) : 1994 - 2003.

Wójcik A., T.Nałęcz-Tarwacka and M. Gołębiewski, 2013. Comparison of calves' rearing parameters in two different housing systems: indoor versus outdoor hutches. Archiv Tierzucht, 56 (63): 628637.

Xiccato G., P.I. Angela Trocinoa., A. Queaquea and A. Sartoria, 2002. Carazzolob. Rearing veal calves with respect to animal welfare: effects of group housing and solid feed supplementation on growth performance and meat quality. Livestock Production Science, 75 (3): 269-280.

Zinn S. A., L. T. Chapin and H. A. Tucker, 1986a. Response of body weight and clearance and secretion rates of growth hormone to photoperiod in Holstein heifers. J. Anim. Sci, (62):1273.

Zinn S. A., L. T. Chapin, W. J. Enright and H. A. Tucker, 1986b. Body growth and carcass composition responses to photoperiod and plane of nutrition in steers. J. Anim. Sci, 63 (1): 237. 
تأثير نظم الرعاية المختلفة على ألاداء وبعض المقاييس الفسيولوجية للعجول الجاموسى النامية خلال فترة التسمين محترم عبدالله محمد ابراهيم' و محمد يوسف العارف` و عبدالرحمن ابراهيم زنونى؟

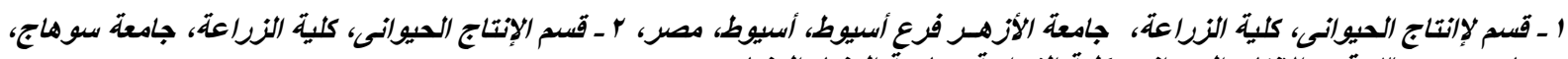

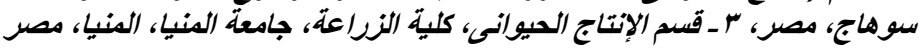

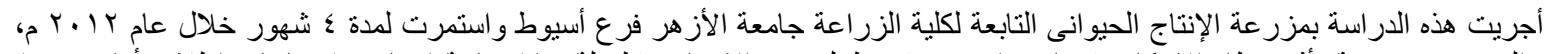

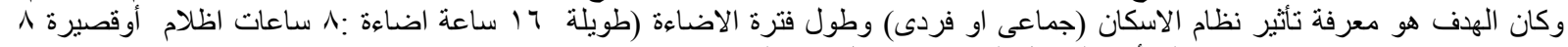

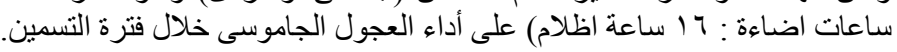

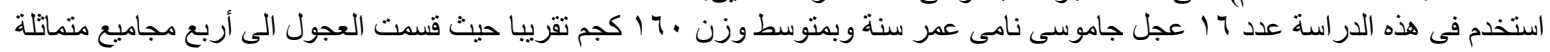

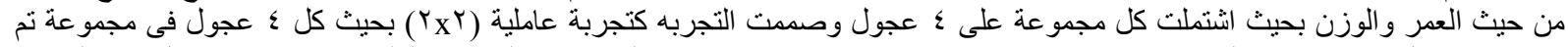

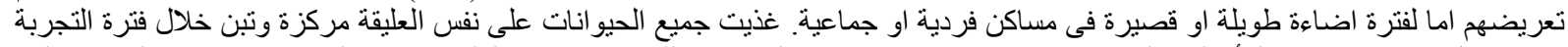

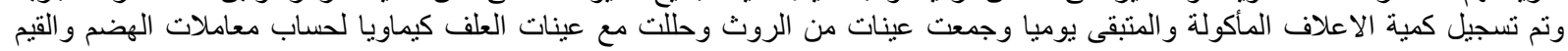

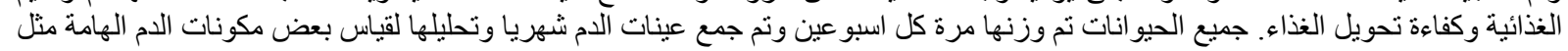

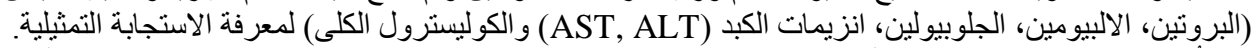

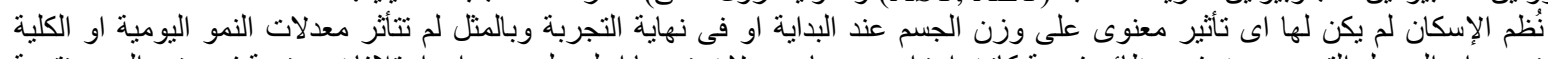

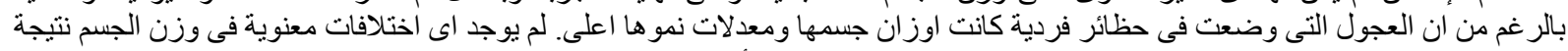

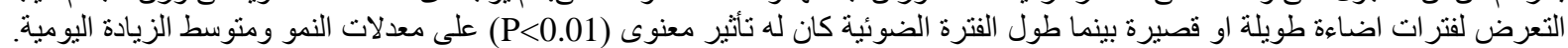

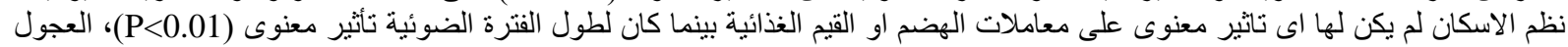

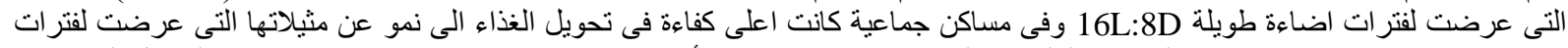

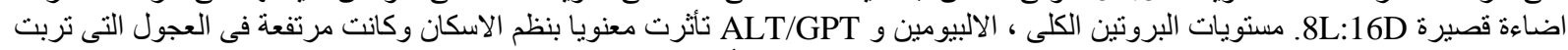

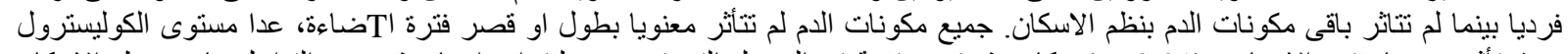

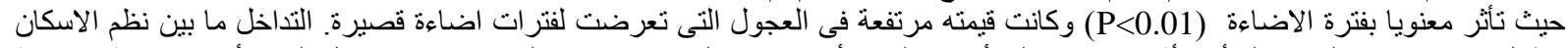

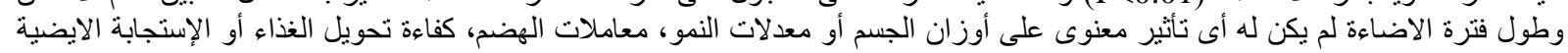

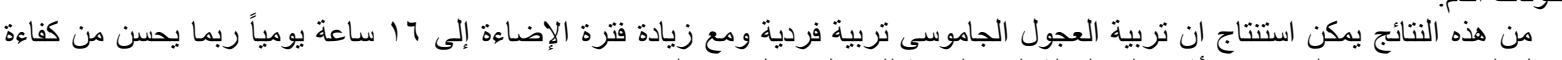
تحويل الغذاء هذه الدات

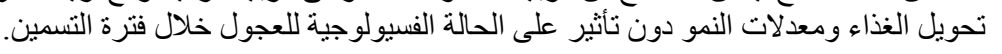

